\title{
Designing Emotion Interface in E-Learning Application for Children
}

\author{
Magrizef Gasah, Aslina Baharum, Nurul Hidayah Mat Zain
}

\begin{abstract}
This paper demonstrates an outline of techniques in structuring enthusiastic interfaces for portable software. The skip for this paper is to analyze and alter a way, particularly as passionate interface method for making u.S.That could trigger customer's sure feelings. The effective emotions evoked through the UI configuration ought to impacts clients' popularity, for example, their advantage and interest any area the plan grow to be related in on line or transportable based. The approach comprise of 3 levels; level one is the shape of a calculated device, degree is the improvement of versatile software program, and degree three is the evaluation of the actualized theoretical tool in portable software program. Via adjusting the approach, the bendy application may additionally make powerful feelings within the course of youngsters studying process.
\end{abstract}

Record terms: Emotional, Interface, methodology, design, Emotion.

\section{INTRODUCTION}

Understudies can cope with the scholarly problems successfully while their executed a tremendous feeling in school. whilst the bad feelings may make understudies endeavor doing their paintings all the greater barely, such despondency will provoke social confinement and evasion to understudies where such trouble may want to prompt scholarly sadness in youngsters or youths $[1,2]$. for this reason, by way of creating a wonderful feeling in gaining knowledge of for youngsters may want to cause them to all of the more captivating in school on account that youngsters will advantage talent with the most fundamental part of records in kindergarten. this is suggest on the off chance that they may be no longer eager on gaining knowledge of, they would confront trouble when maintain on standard faculty. furthermore, school exercises that might draw out understudies' feelings, agreeable assignment and pretending, can also provide significant relevant memory updates that might enable understudies to study the statistics through firmly associated sports in truth [3]. The interface configuration can draw in the clients' emotions and more basis whilst the kids are the customers. maximum smart objects that have been made for youngsters certainly have instructive factors. numerous instructive and mental fields moreover concurred that sort of tremendous emotions assumes substantial jobs in advancing children intellectual improvement and mastering $[4,5,6]$.

Revised Version Manuscript Received on August 19, 2019.

Magrizef Gasah, Faculty of Computing and Informatics, Universiti Malaysia Sabah, Kota Kinabalu, Sabah, Malaysia.

Aslina Baharum, Faculty of Computing and Informatics, Universiti Malaysia Sabah, Kota Kinabalu, Sabah, Malaysia

Nurul Hidayah Mat Zain, Faculty Computer and Mathematical Sciences, Universiti Technology MARA (UiTM), Cawangan Melaka, Kampus Jasin, Merlimau, Melaka, Malaysia. moreover, kids feelings in instructive interfaces simply ought to accomplish more than enhancing the interface great but further assumes a critical task in achieving the object getting to know goals [7]. In mild of the hypothesis and the vast of effective feeling for youngsters, it is crucial to have a valid research in technique for recognizing the enthusiastic interface. This consists of the improvement an applied gadget recognized with UI enthusiastic plan to make a effective feeling in the direction of children where it contains of the hypothesis of feelings and interfaces structure. The calculated machine should characterize the advantageous enthusiastic affiliation and how to apply in the advancement stage. After the improvement level, the execution of the sensation and usaconfiguration ought to had been assessed so that it will verify the unwavering high-quality and legitimacy of the applied device. kids commitment in school is basic and vast where it have to had been increased as a way to preserve them from losing out of faculty. As an early hobby to make kids eager on studying at college, giving them a effective feeling and involvement in gaining knowledge of is a want.

\section{ASSOCIATED WORKS}

Inside the ongoing years, the versatile advances received such enormous ground in its development. The innovations have evolved till it turns out to be a piece of our every day life [8]. Sooner or later, it is straightforward the ample enthusiasm for the usage of versatile innovation inside the education. A couple of years previous, the educating rehearses that available and related to laptop devices were the prevalent studying (u-learning) separation and mastering (e-gaining knowledge of). Currently, it's far the transportable learning (m-realizing) that becomes the attention of diverse researchers and work on its advancement and appropriation from anywhere during the arena $[9,10,11]$. The term of the $\mathrm{m}$-studying speaks to the utilization of the flexible utility within the coaching technique at schools in which packages brought on a mobile smartphone, for instance, in pill or cellular phone [12].

The m-mastering execution is not a easy manner in particular when it supposed for little kids. This given that, it is not just firmly associated with the writers of the reading cloth yet similarly the kids (understudies), teachers, and guardians who impact kids factor of view to peer the outside world. the ones human beings count on a vast process inside the development of the kids hobbies, social conduct and individual [13]. in this way, the vast of $\mathrm{m}$-gaining knowledge

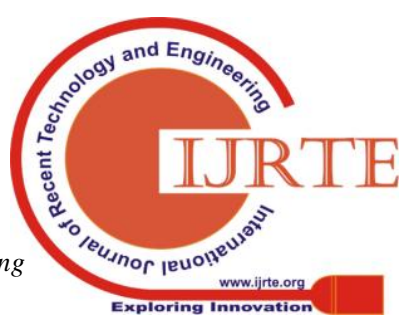


of for children cannot be denied and it is a need for early children to fabricate their character, behavior and enthusiasm for studying. in the beyond research of user Interface design (UID), it turned into strengthened that it's far critical to contain ergonomic proposals, utilize a customer targeted technique, or "incredible ideas" [14, 15]. The research of UID ought to distinguish and arrange the passionate reaction from a specific plan. table 1 demonstrates the prevailing investigation on the feeling plan in UID. Irregularity in the layout will make patron felt unhappy and awkward with the plan. that is a similar whilst taking a gander on the thoughts boggling layout where reason dissatisfaction in consumer on the grounds that they could not understand in which to the unique ability is determined. subsequent, some shading inside the plan ought to impact client to felt and thinks in spite of the fashion of the format.

Table 1: Current Study of Emotion Design on Layout, Color and Typography

\begin{tabular}{|c|c|c|c|}
\hline No & User Interface Design with Emotion & Result & Source \\
\hline \multirow[t]{3}{*}{1} & \multicolumn{3}{|l|}{ Layout } \\
\hline & $\begin{array}{l}\text { Different layout applied in website and } \\
\text { apps such as follow standard layout, use } \\
\text { grid, more whitespace, Portrait and } \\
\text { Landscape }\end{array}$ & $\begin{array}{l}\text { Consistency in layout could produce } \\
\text { satisfaction emotion }\end{array}$ & [16] \\
\hline & $\begin{array}{l}\text { The impact of the layout to visually } \\
\text { impaired users' navigation behaviour and } \\
\text { the relationship between the user's } \\
\text { emotions and their navigation behaviour in } \\
\text { a complex layout. }\end{array}$ & $\begin{array}{l}\text { Complex layout change user emotion } \\
\text { from positive to negative valence. }\end{array}$ & [17] \\
\hline \multirow[t]{3}{*}{2} & \multicolumn{3}{|l|}{ Color } \\
\hline & $\begin{array}{l}\text { Every colour could elicit a different and } \\
\text { unique emotional response in the viewer, } \\
\text { and a clever web designer will know the } \\
\text { effect of each colour, plus when and how } \\
\text { to use each of them. }\end{array}$ & $\begin{array}{l}\text { Orange (Energetic, Playful, Cheap) } \\
\text { Green (Stable, Natural, Prosperous) } \\
\text { Pink (Young, Feminine, Innocent) } \\
\text { Blue (Serene, Trustworthy, Inviting) } \\
\text { Purple (Luxurious, Mysterious, } \\
\text { Romantic) } \\
\text { Brown (Rustic, Earthy, Sturdy) } \\
\text { Black (Edgy, Powerful, Sophisticated) } \\
\text { Yellow (Happy, Warning, Friendly) } \\
\text { Red (Aggressive, Passionate, Important) } \\
\text { White (Clean, Virtuous, Healthy) } \\
\text { Grey (Neutral, Formal, gloomy) }\end{array}$ & {$[18]$} \\
\hline & $\begin{array}{l}\text { The psychology of colour is based on } \\
\text { the mental and emotional effects colours } \\
\text { have been seen on people in all facets of } \\
\text { life. There are some very subjective pieces } \\
\text { to colour psychology as well as some more } \\
\text { accepted and proven elements. Keep in } \\
\text { mind, that there will also be variations in } \\
\text { meaning, perception and interpretation. }\end{array}$ & $\begin{array}{l}\text { White (Purity, Innocence, Cleanliness) } \\
\text { Black (Authority, Power, Evil, Death) } \\
\text { Red (Love, Romance, Comfort, Energy) } \\
\text { Orange (Happy, Warmth, Excitement) } \\
\text { Grey (Neutral, Timeless, Practical) } \\
\text { Green (Natural, Cool, Growth, Money, } \\
\text { Tranquillity) } \\
\text { Yellow (Happiness, Laughter, Hunger, } \\
\text { Intensity) } \\
\text { Blue (Calmness, Serenity, Cold, } \\
\text { Wisdom, Loyalty) } \\
\text { Brown (Stability, Reliability, } \\
\text { Friendship, Sadness, Organic) } \\
\text { Purple (Wisdom, Exotic, Spiritual, } \\
\text { Mystery) (Agitation, Romance, Gentle, } \\
\text { Pink (ave } \\
\text { Love) }\end{array}$ & [19] \\
\hline
\end{tabular}




\begin{tabular}{|c|c|c|c|}
\hline \multirow[t]{2}{*}{3} & \multicolumn{3}{|l|}{ Typography/Typeface } \\
\hline & $\begin{array}{l}\text { Experiment on three types of typeface } \\
\text { that include: } \\
\text { i. Palatino } \\
\text { ii. Helvetica } 65 \text { Neue Medium. } \\
\text { iii. PAP }\end{array}$ & $\begin{array}{l}\text { Palatino } \\
\text {-Sympathetic, sensitive, interest. } \\
\text { Helvetica } 65 \text { Neue Medium. } \\
\text {-Stimulated, excited, exuberant, alive, } \\
\text { aroused } \\
\text { PAP } \\
\text {-Sympathetic, sensitive, interest, } \\
\text { nostalgic, haughty }\end{array}$ & [20] \\
\hline & $\begin{array}{l}\text { The typographic-design experts agree } \\
\text { that the majority of fonts have the } \\
\text { potential to elicit emoional responses from } \\
\text { users. }\end{array}$ & $\begin{array}{l}\text { The responses of emotional usually } \\
\text { determined by usability of the design, style, } \\
\text { form and function. }\end{array}$ & {$[21]$} \\
\hline
\end{tabular}

As in keeping with [18] who've over 10 years in growing internet site, the coloration of purple may additionally need to cause the irate feeling to consumer, wherein some idea have to have been taken in advance than making use of this kind of shading. The typography and the typeface likewise may want to trigger some enthusiastic response to watcher. As constant with [21], the enthusiastic response generally dictated with the useful resource of ease of use of the plan, fashion, structure and potential of the typeface and this end up bolstered via an investigation via [22].

\section{A. Categorization and Contrasting emotions}

The arrangement and differentiating of feelings depict how emotions are linked and numerous to each other. As in keeping with [23], people may want to come across emotions via evidence that might impact the conduct, interest and issues. These feelings is probably organized into distinct influences that evaluate to the triumphing scenario of the human. To installation the emotions, it is crucial to distinguish the essential diploma of feeling [24].

\section{B. Modelling primary Emotion}

To be able to discover the fundamental feeling of most human, this exploration has considered adjusting the effect of the past analyst's aftereffect of the maximum vital human feeling and precise to each different. The feelings are recorded as appeared in table 2 .

Table 2: List of Basic Emotion from Researcher

\begin{tabular}{|c|c|c|c|}
\hline Source & List of Distinct Emotions & & Basic Emotion \\
\hline [25] & $\begin{array}{l}\text { Anger, Disgust, Fear, } \\
\text { Sadness }\end{array}$ & $\begin{array}{l}\text { Anticipation, Joy, Surprise, } \\
\text { Trust }\end{array}$ & \multirow{3}{*}{$\begin{array}{lr}\text { Admiration, } & \text { Adoration, } \\
\text { Aesthetic } & \text { Appreciation, } \\
\text { Amusement, } & \text { Anger, } \\
\text { Anticipation, } & \text { Anxiety, } \\
\text { Appreciation, } & \text { Awe, } \\
\text { Awkwardness, } & \text { Boredom, } \\
\text { Contempt, } & \text { Calmness, } \\
\text { Confusion, Craving, Disgust, } \\
\text { Entrancement, Empathetic Pain, } \\
\text { Envy, Excitement, Fear, Guilt, } \\
\text { Horror, Interest, Joy, Nostalgia, } \\
\text { Pride, Pleasure, Pity, Relief, } \\
\text { Romance, Sadness, Satisfaction, } \\
\text { Shame, Sexual desire, Surprise, } \\
\text { Sympathy, } \\
\text { Triumph, Trust Tenderness, }\end{array}$} \\
\hline [26] & $\begin{array}{l}\text { Anger, Interest, } \\
\text { Amusement, Pride, Joy, } \\
\text { Pleasure, Tenderness, Awe, } \\
\text { Relief, Surprise }\end{array}$ & $\begin{array}{l}\text { Nostalgia, Pity, Sadness, Fear, } \\
\text { Shame, Guilt, Regret, Envy, } \\
\text { Disgust, Contempt }\end{array}$ & \\
\hline [27] & $\begin{array}{lr}\text { Adoration, } & \text { Admiration, } \\
\text { Aesthetic } & \text { Appreciation, } \\
\text { Amusement, } & \text { Anxiety, } \\
\text { Awe, } & \text { Awkwardness, } \\
\text { Boredom, } & \text { Calmness, } \\
\text { Confusion, } & \text { Craving, } \\
\text { Disgust, Empathetic Pain }\end{array}$ & $\begin{array}{l}\text { Entrancement, } \\
\text { Excitement, Fear, Horror, } \\
\text { Interest, Joy, Nostalgia, } \\
\text { Romance, } \\
\text { Satisfaction, Sexual desire, } \\
\text { Sympathy, Triumph }\end{array}$ & \\
\hline
\end{tabular}

\section{A.Contrasting key Emotion dependent on superb and poor Emotion}

in venture with [28], the basic premise in the class of the simple feeling is that the definition and utilizing the expression feeling that commonly in regards to a fine kind of scholarly appreciate need to be comprehended [28]. it is routinely used to allude the scholarly appreciate with solid inspiring emotional improvements much like the fundamental impressions of either throb or fulfillment. based absolutely at the guidelines [28], one can likewise need to make an unmistakable qualification between the 'feelings', 'sensations' and 'sentiments' wherein those should choose out the possibility of feelings and gifted through every single regular individuals and must be depicted in comparable terms with the guide of exact individuals. table 2 demonstrates the customized model of the terrible and top of the line feeling style based totally at the essential feeling in table three. 
DESIGNING EMOTION INTERFACE IN E-LEARNING APPLICATION FOR CHILDREN

Table 3. Classification of basic emotion to positive emotion and negative emotion

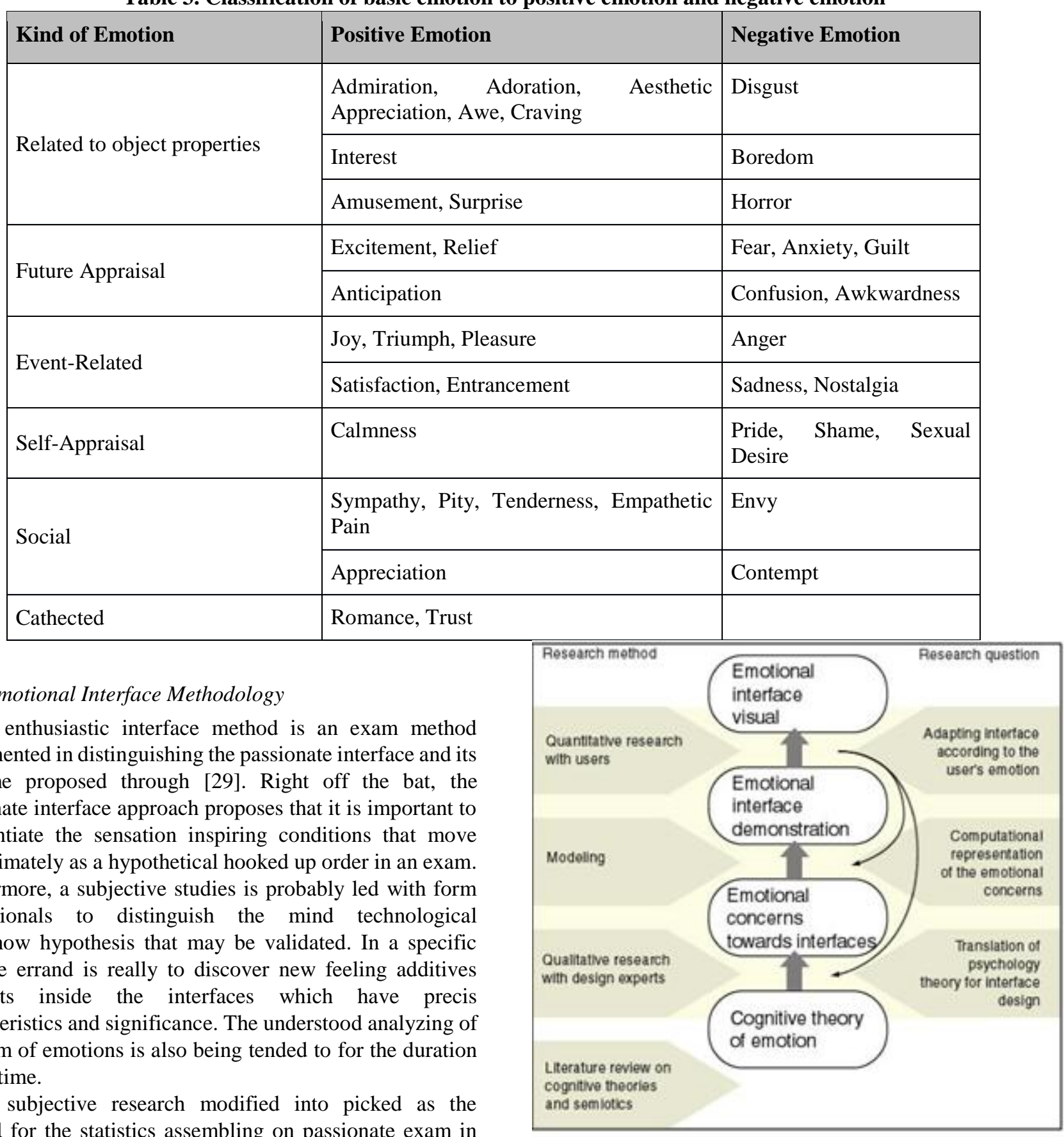

Figure 1: Emotional Interface Methodology

\section{RESULTS \& DISCUSSIONS}

The examination method of this exploration became adjusted from the enthusiastic interface method in determine 1. Along those traces, this examination will revel in three (three) degrees in which every degree allows within the development and confirmation of the nice enthusiastic of the version in a proper framework, which inspires expert to discover extra at the innovative troubles of the model. At remaining, to approve the consequences of the model and further discoveries and look at, quantitative studies way is chosen to evaluate the execution. 
interface method. Those degree move about because the intention of this exam and it is critical to accomplish the goal consecutively. At the same time as sporting out every duration of the examination, some exploration machine has been adjusted. If you want to accomplish the level 1 aim, writing audit at the passionate hypothesis have been directed together with the subjective research with the regular aim purchaser.

Diploma 1 will distinguish the low-cost shape of ui plan that noteworthy with passionate form. Degree 2 is the location the advancement stage takes place through utilising the idea in stage 1 and the enthusiastic association that is probably made via bendy packages. That permits you to accomplish the target of level 2, the method applied in the development system is transportable $\mathrm{d}$ system wherein it a spry improvement method appropriate for bendy improvement. Degree three will verify the passionate affiliation activated via manner of the flexible programs created and the adjusted research approach is the [30] emotional rating and the 6 basic facial expression by [31]

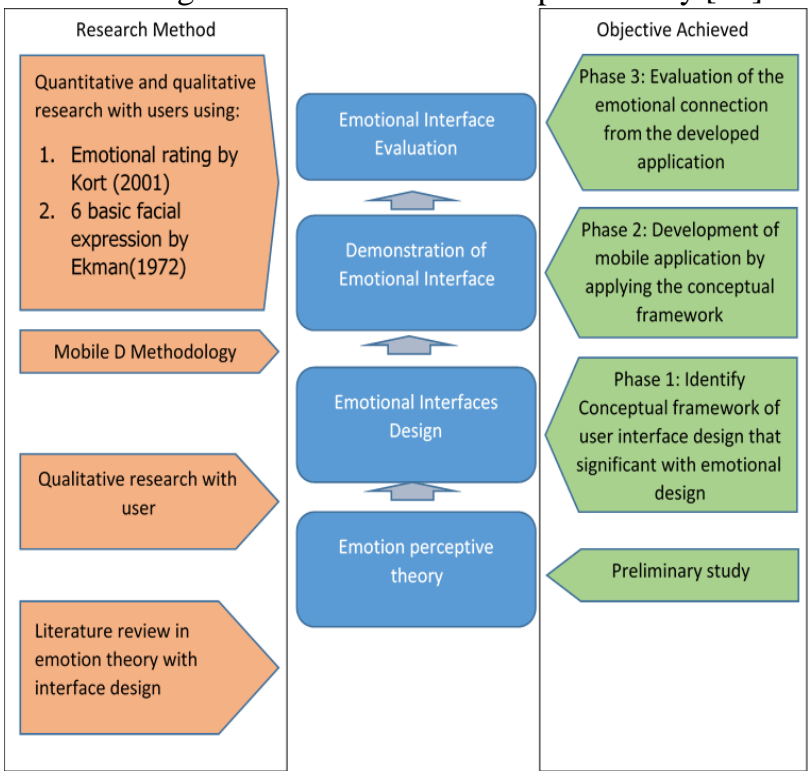

Figure 2: Positive Emotional Interface Methodology

Fundamental observe. A primer file is critical to be directed so as to distinguish the feeling felt through children whether or not it's miles a positive or negative feeling. This to guarantee that whether or not it's miles viable to catch the sensation from the objective customer or no longer. The enthusiastic interface plan and its passionate speculation is utilized together with an utility that have been chosen to find out the apprehend the enthusiastic affiliation and its passionate reaction.

Level 1: This level concentrating on the creation the theoretical system for the utility. Consequently, a few writing survey need to were carried out on the modern enthusiastic hypothesis in order to realise the idea of passionate association and enthusiastic structure. The identification of this sense evoking conditions is fundamental for the hypothetical established order of the exploration. The development of a passionate interface required appropriates, extensive, and settled upon hypothesis, which may be adjusted in the structure [29]. After the hypothesis were gathered and had been audit, a few statistics have to be collected to recognize the genuine feeling activated through the UI seeing that the hypothesis include part of feeling, this to demonstrate the hypothesis and just targeting unmarried feeling as it had been. After the statistics accumulations were accomplished, the sensation is than to be characterized into superb and negative emotions wherein the terrible feelings have to were taken out structure the rundown. Sooner or later, the aftereffect of the feeling grouping is that the fine feeling is applied to make the affordable shape.

Degree 2: The theoretical structure of creating the consumer Interface design with nice feeling from the stage 1 can be connected on the improvement of a versatile software. This is to assure that the created software could make a fine enthusiastic association when the customers make use of the application. The advancement strategy for the flexible application is the portable $\mathrm{d}$ method where it contains of five stages, which include discover, Initialize, Productionize, Stabilize, framework take a look at and fasten.

Degree 3: This degree worries with the created application whether or not it could truly trigger the youngsters feeling or no longer. At some point of the assessment period of the theoretical machine appear whether or not it may without a doubt trigger the fantastic feeling to the member or now not. The assessment technique contains of quantitative research method. The methodologies applied are the [30] passionate score and 6 essential outward appearances by using [31]. The two methodologies are large and could distinguish the high quality feeling estimation of the created flexible application.

\section{END}

For quit, this exploration paper demonstrates a big direction in development of effective passionate response thru UI structure. The regular result of this exploration is that the youngsters could be step by step eager on getting the hold of using e-gaining knowledge of utility in mild of the utility is created depending on specific UI structure within the calculated machine that might supply the youngsters superb feeling and experience. The high-quality feeling skilled by way of customers is vital to drag within the client intrigue and supporting the patron to make use of the application. This nice passionate interface method could assist in e-getting to know utility as well as may want to assist inside the development of framework application, for example, web site, on-line business, item that identified with UI, and so forth. With the aid of comprising of three ranges, the high quality enthusiastic interface device may want to recognize any passionate response as lengthy all matters considered with the speculation of feeling and shape, next the affordable structure could be completed in a targeted on stage of machine, at that factor the assessment of the hypothesis that extraordinarily crucial to illustrate adequacy of implemented machine.

\section{AFFIRMATION}

This exam is coordinated effort among Universiti Malaysia Sabah (UMS) and university generation MARA (UiTM), Cawangan Melaka, Kampus Jasin. We might need to thank the Institute of research control and Innovation (IRMI) UiTM and Engin

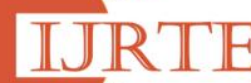

\& Sciences Publication 
for supporting this exploration thru iRAGS award 600-RMI/IRAGS 5/three (2/2015). We likewise might want to provide our way to who were legitimately or in a roundabout manner engaged with this investigation.

\section{REFERENCES}

1. E. Aronson, constructing sympathy, empathy, and accomplishment inside the jigsaw look at corridor, improving scholarly accomplishment: impact of mental factors on schooling. (2002) 209-25.

2. J.G. Parker, S.R. Asher, Friendship and kinship first-class in middle young people: links with companion bunch acknowledgment and sentiments of melancholy and social sadness. Formative brain technological know-how. (1993) Jul; 29(four) 611 .

3. R. Sylwester, How emotions influence gaining knowledge of, instructional authority, (1994) 52(2):60-five

4. Four. R.F. Bornstein, exposure and impact: overview and meta-investigation of research, 1968-1987. Mental Bulletin, 106(2) (1989) 265-289.

5. Five. J.L. Delin, A. Hartley, C.L. Paris, D.R. Scott, and okay.V. Linden, Expressing procedural dating in multilingual guidance. In continuing of the 7 th common Workshop on natural Language technology (1994), pp. 61-78, Kennebunkport, Maine, June.

6. 6. L.G. Edgar, J.D. McGhee, DNA mixture and the manipulate of embryonic fine articulation in C. Elegans, branch of scientific Biochemistry university of Calgary, Alberta Canada T2N 4N1 (1988)

7. 7. E. Strommen and okay. Alexander, Emotional Interfaces for Interactive Aardvarks: structuring have an effect on into social interfaces for children (1999), Proc CHI 99 ACM, may.

8. 8. M. Sarwar, T.R. Soomro, "impact of telephone's on Society", ecu diary of logical studies, vol. Ninety eight (2), p. 216-226 (2013)

9. 9. T.M. Cumming, "continuing transportable getting to know: principle, studies, and practice", launch: first, distributer: Routledge, proofreader: $\mathrm{Ng}, \mathrm{W}$. And Cumming, T., ISBN: 978-1-138-78738-4 (2015).

10. 10. D. Donchev, I. Hristov, "flexible getting to know programs pervasive features and modern arrangements", journal of laptop science and information advances, vol. 6, no three, Sofia (2006).

11. Eleven. G. Botzer, M. Yerushalmy, "versatile utility for transportable getting to know", IADIS international convention on Cognition and Exploratory learning in digital Age (CELDA 2007), Portugal (2007).

12. 12. D. Parsons, H. Ryu, "A system for surveying the nature of versatile learning", in approaches of the 11th worldwide conference for manner development, research and education (inspire), Southampton Solent university, united kingdom (2006).

13. 13. J.S. Eccles, P.E. Davis-Kean, "impacts of guardians' schooling on their youngsters' instructive accomplishments: the job of discern and tyke recognitions", London survey of schooling, vol. (3), pp. 191-204 (2005).

14. 14. Norman, D.A., Emotion and structure: appealing matters paintings higher. Connections mag, ix (4):36-forty two (2002)

15. 15. Shneiderman, B., nice, C., Designing the person Interface: techniques for effective Human-computer interaction, fourth edition, Buston, MA: Addison Wesley. (2005)

16. Sixteen. J. Mendel, R. Park, The impact of Interface Consistency and Cognitive Load on customer execution in a statistics seek venture, Human elements and Ergonomics Society Annual meeting proceedings. (2009)

17. 17. B. Ramayah, A. Jaffar, expertise The effect Of net layout And Emotional changes in the direction of Navigation behavior amongst Visually Impaired customers. Diary of Theoretical and carried out records technology, Malaysia (2005)

18. 18. J. Cao. Recovered St Martin's Day 2017 at: http://www.Creativebloq.Com/internet site composition/12-colors and-emotions they-convey out 61515112, (2017).

19. 19. Artwork therapy. Recovered 18 December 2017 at: http://www.Arttherapyblog.Com/on the net/shading brain science psychologica-impacts of-colorings/(2017).

20. 20. Okay.L. Guthrie. Enthusiastic response To Typogrpahy: The position Of Typographic variations In Emotional response To advertising. College Of Florida (2009)

21. 21. A.G. Ho. Typography nowadays: Emotion recognition in Typography. City university of Hong Kong. (2013)

22. 22. Guthrie1, J.T., Klauda, S.L., Ho, A.N., Modeling the connections amongst perusing guidance, suggestion, dedication, and accomplishment for younger humans. Perusing studies Quarterly. 2013;48(1):9-26.

23. 23. L.F. Barrett, Are emotions natural types?, Sage journal 1(1) 28-fifty eight (2006).

24. 24. R.S. Edelstein, P.R. Shaver, A move-Cultural exam of Lexical research of Self-conscious feelings. The unsure feelings: idea and research, 194-208 (2007).

25. 25. R. Plutchik, the character of Emotion. University Of South Florida (2001).

26. 26. V. Sacharin, k. Schlegel, and ok.R. Scherer, Geneva Emotion Wheel rating have a look at. Geneva, Switzerland: university of Geneva, Swiss middle for Affective Sciences (2012).

27. 27. A.S. Cowen, D. Keltner, Self-record catches 27 unmistakable classes of feeling crossed over by way of consistent dispositions. Distributed by way of: country wide Academy of Sciences (2017), Print ISSN: 0027-8424. Online ISSN: 1091-6490.

28. 28. D.L. Robinson, mind work, enthusiastic revel in and man or woman, Netherlands journal of Psychology 64: 152-167 (2008).

29. 29. S. Tzvetanova, Emotional Interface methodology. Worldwide relationship of social orders of configuration look into, The Hong Kong Polytechnic university (2007)

30. 30. Kort, B. Also, Reilly, R. (2001). "Systematic fashions of emotions, learning and Relationships: towards an affect-touchy Cognitive machine," M.I.T

31. 31. Ekman, P. (1999), "essential emotions," published with the aid of university of California, San Francisco, CA, u.S.A 